\title{
Herbal medicine use in the districts of Nakapiripirit, Pallisa, Kanungu, and Mukono in Uganda
}

\author{
John RS Tabuti i* Collins B Kukunda ${ }^{2}$, Daniel Kaweesi ${ }^{3}$ and Ossy MJ Kasilo ${ }^{4}$
}

\begin{abstract}
Background: Traditional medicine (TM) occupies a special place in the management of diseases in Uganda. Not with standing the many people relying on TM, indigenous knowledge (IK) related to TM is getting steadily eroded. To slow down this loss it is necessary to document and conserve as much of the knowledge as possible. This study was conducted to document the IK relevant to traditional medicine in the districts of Mukono, Nakapiripirit, Kanungu and Pallisa, in Uganda.
\end{abstract}

Methods: An ethnobotanical survey was conducted between October 2008 and February 2009 using techniques of key informant interviews and household interviews.

Results: The common diseases and conditions in the four districts include malaria, cough, headache, diarrhea, abdominal pain, flu, backache and eye diseases. Respondents stated that when they fall sick they self medicate using plant medicines or consult western-trained medicine practitioners. Self medication using herbal medicines was reported mostly by respondents of Nakapiripirit and Mukono. Respondents have knowledge to treat 78 ailments using herbal medicines. 44 species, mentioned by three or more respondents have been prioritized. The most frequently used part in herbal medicines is the leaf, followed by the stem and root. People sometime use animal parts, soil, salt and water from a grass roof, in traditional medicines. Herbal medicines are stored for short periods of time in bottles. The knowledge to treat ailments is acquired from parents and grandparents.

Respondents' age and tribe appears to have a significant influence on knowledge of herbal medicine, while gender does not.

Conclusion: This survey has indicated that IK associated with TM stills exists and that TM is still important in Uganda because many people use it as a first line of health care when they fall sick. Age and tribe influence the level of IK associated with herbal medicine, but gender does not.

Keywords: Ethnomedicine, Traditional medicine, Health seeking behaviour

\section{Introduction}

Traditional medicine (TM) has been used by humans for thousands of years. The World Health Organization (2002), defines traditional medicine, in part, as a medicine system that includes medication therapies like herbal medicines as a well as non-medication therapies like acupuncture. The same organization defines herbal medicines to include herbs, herbal materials, herbal

\footnotetext{
* Correspondence: jtabuti@muienr.mak.ac.ug

${ }^{1}$ Makerere University, College of Agricultural and Environmental Sciences (MUCAES), P.O. Box 7062, Kampala, Uganda

Full list of author information is available at the end of the article
}

preparations and finished herbal products, that contain as active ingredients parts of plants, or other plant materials, or combinations thereof. The World Health Organization (WHO) estimates that $80 \%$ of the population living in developing countries uses TM for their primary health care needs [1]. However, this percentage varies from country to country. For instance, $90 \%$ of the population in Ethiopia, $70 \%$ in Rwanda, and $60 \%$ in Uganda and Tanzania use TM for their PHC [2]. TM is widely used in Uganda for the prevention, diagnosis and treatment of social, mental and physical illness [3]. Although a diversity of material - plant, animal and

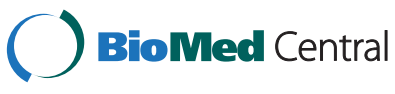


inorganic material - are used in traditional medicines, plants dominate.

In Uganda, households possess indigenous knowledge of traditional cures for non complicated ailments. On the other hand, Traditional medicine practitioners (TMPs) are an invaluable source of specialized knowledge about TM and are very important human resources for the practice and delivery of primary health care services [3]. The WHO recognizes the invaluable role of TM and its practitioners, and it is for this reason that the Alma Ata Declaration of 1978 recommended that TM and its practitioners should be integrated into primary health care programmes [4] as important resources for achieving health for all.

Although a majority of people rely on TM, indigenous knowledge (IK) related to TM is getting steadily eroded[ 5]. It is believed that this is a consequence of people adopting new lifestyles and migrating to urban centers [6]. Other workers have identified lack of confidence among users and practitioners as a cause of loss of

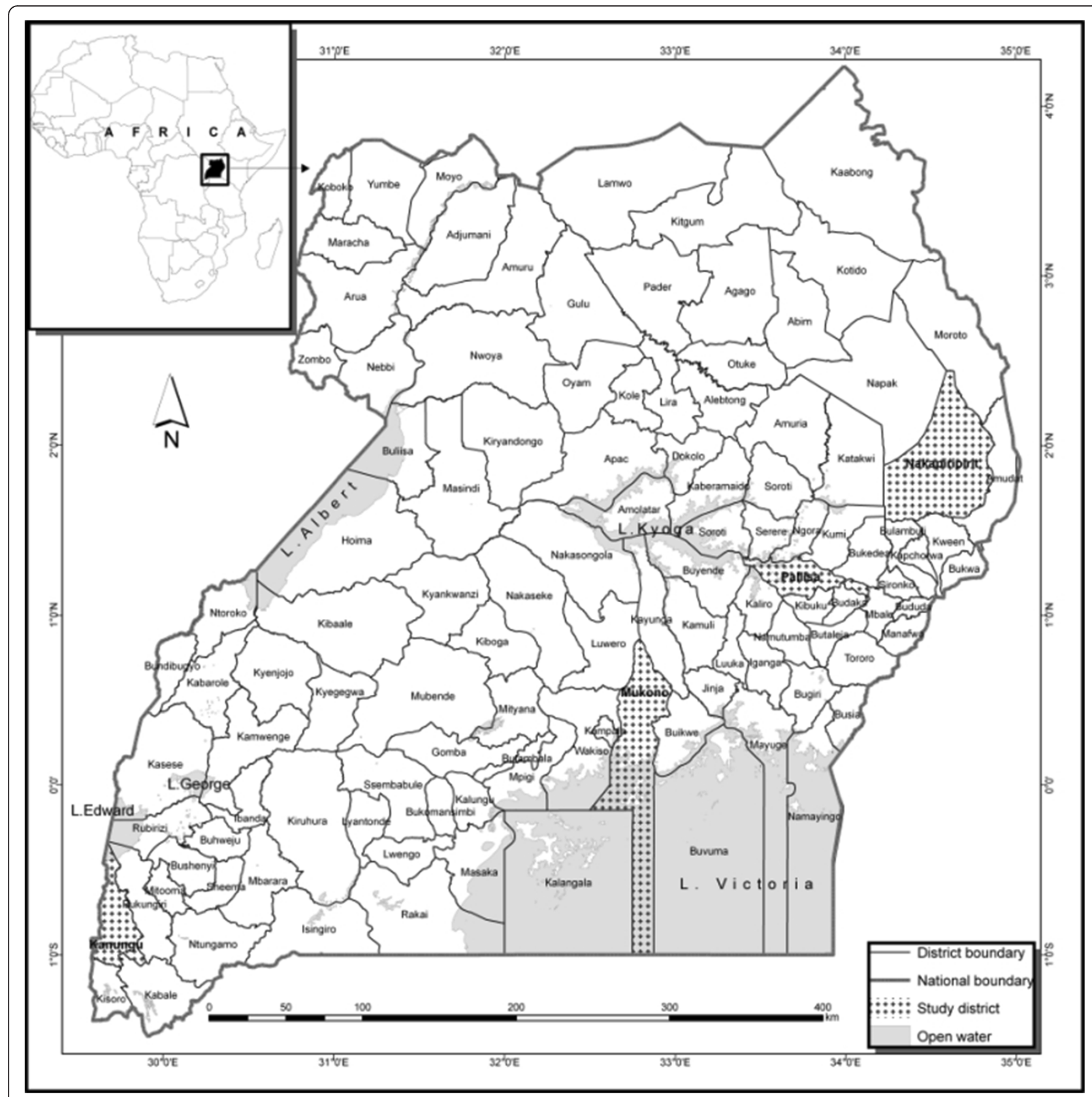

Figure 1 Map of Uganda showing the four study districts, Nakapiripirit, Mukono, Kanungu and Pallisa (shaded on the map). Inset is a map of Africa. 
Table 1 Respondent characteristics $(n=171)$

\begin{tabular}{|c|c|}
\hline Characteristic & Percent \\
\hline \multicolumn{2}{|l|}{ Education of respondent } \\
\hline Primary & 59 \\
\hline None & 23 \\
\hline Lower secondary & 11 \\
\hline Tertially & 4 \\
\hline Higher secondary & 2 \\
\hline University & 1 \\
\hline \multicolumn{2}{|l|}{ Religion } \\
\hline Catholic & 61 \\
\hline Anglican & 31 \\
\hline Moslem & 7 \\
\hline Adventist & 1 \\
\hline Yudaya & 1 \\
\hline \multicolumn{2}{|l|}{ Tribe } \\
\hline Karamojong & 30 \\
\hline Mukiga & 23 \\
\hline Muganda & 20 \\
\hline Mugwere & 19 \\
\hline Iteso & 2 \\
\hline Musoga & 1 \\
\hline Tanzanian & 1 \\
\hline Munyarwanda & 1 \\
\hline Mulundi & 1 \\
\hline Munyole & 1 \\
\hline Mukonjo & 1 \\
\hline \multicolumn{2}{|l|}{ Occupation of respondent } \\
\hline Farmer & 42 \\
\hline Student & 22 \\
\hline Pastoralist & 20 \\
\hline Civil servant & 7 \\
\hline Housewife & 3 \\
\hline Business & 1 \\
\hline Crafts Man & 1 \\
\hline Tailor & 1 \\
\hline Mechanic & 1 \\
\hline Traditional Livestock Healer & 1 \\
\hline Watchman & 1 \\
\hline
\end{tabular}

* local name or terminology.

knowledge of TM $[7,8]$. In the African Region, IK is handed down from generation to generation by oral tradition, and sometimes custodians of this knowledge die before passing it on [9].

To control the loss of IK related to TM it is necessary to document and conserve as much of this knowledge as possible in line with WHO policy and as reflected in the different resolutions adopted by the World Health Assembly [10-12] and WHO Regional Committee for Africa $[13,14]$ on TM and medicinal plants. These resolutions urge Member States to among other things, produce inventories of effective practices as well as evidence on safety, efficacy and quality of traditional medicines and undertake relevant research; to take effective measures in collaboration with other partners; to ensure conservation of medicinal plants and encourage their sustainable utilization; and to respect, preserve and widely communicate, as appropriate, the IK and practices.

Previous studies in Uganda have inventoried herbal medicines and associated IK of processing and administration [3], in general ethnobotanical studies or in disease specific inventories such as those targeting malaria, tuberculosis [15], or HIV/AIDS and related conditions [16]. Owing to the wide cultural diversity and ecological diversity a high diversity of IK including that associated with herbal medicines exists in Uganda. However, little of this knowledge has been documented to date. This study complements the earlier studies by extending our knowledge of herbal medicines in four culturally and ecologically diverse regions of Uganda.

\section{Methods}

Field research for this project was conducted between October 2008 and February 2009 in the districts of Mukono, Nakapiripirit, Kanungu and Pallisa (Figure 1). These districts were selected because they are rural and remote with poor infrastructure and service delivery. Rural and remote communities are known to be marginalized in terms of access to health services and suffer high levels of poverty because they lack appropriate means of income generation [9]. These factors force people to use traditional medicine (TM) and keeps the indigenous knowledge associated with TM intact.

The communities in the study districts are ethnically diverse and belong to different tribes. The people of Mukono belong to the Baganda tribe. The people of Nakapiripirit are Ngakarimojong by tribe, those of Kanungu are Bakiga and the ones of Pallisa belong to the tribes of the Ateso and the Bagwere. This implies that they have different IK and exploit useful plants in different ways. All these cultural groups subsist on crop agriculture as their main source of livelihood apart from the Ngakarimajong who are nomadic cattle keepers [17].

Data were collected using an ethnobotanical survey. The survey started off with key-informant interviews that included local politicians, elderly people, and a nursing sister as participants. In the key informants interviews the focus was on understanding health seeking behavior. 


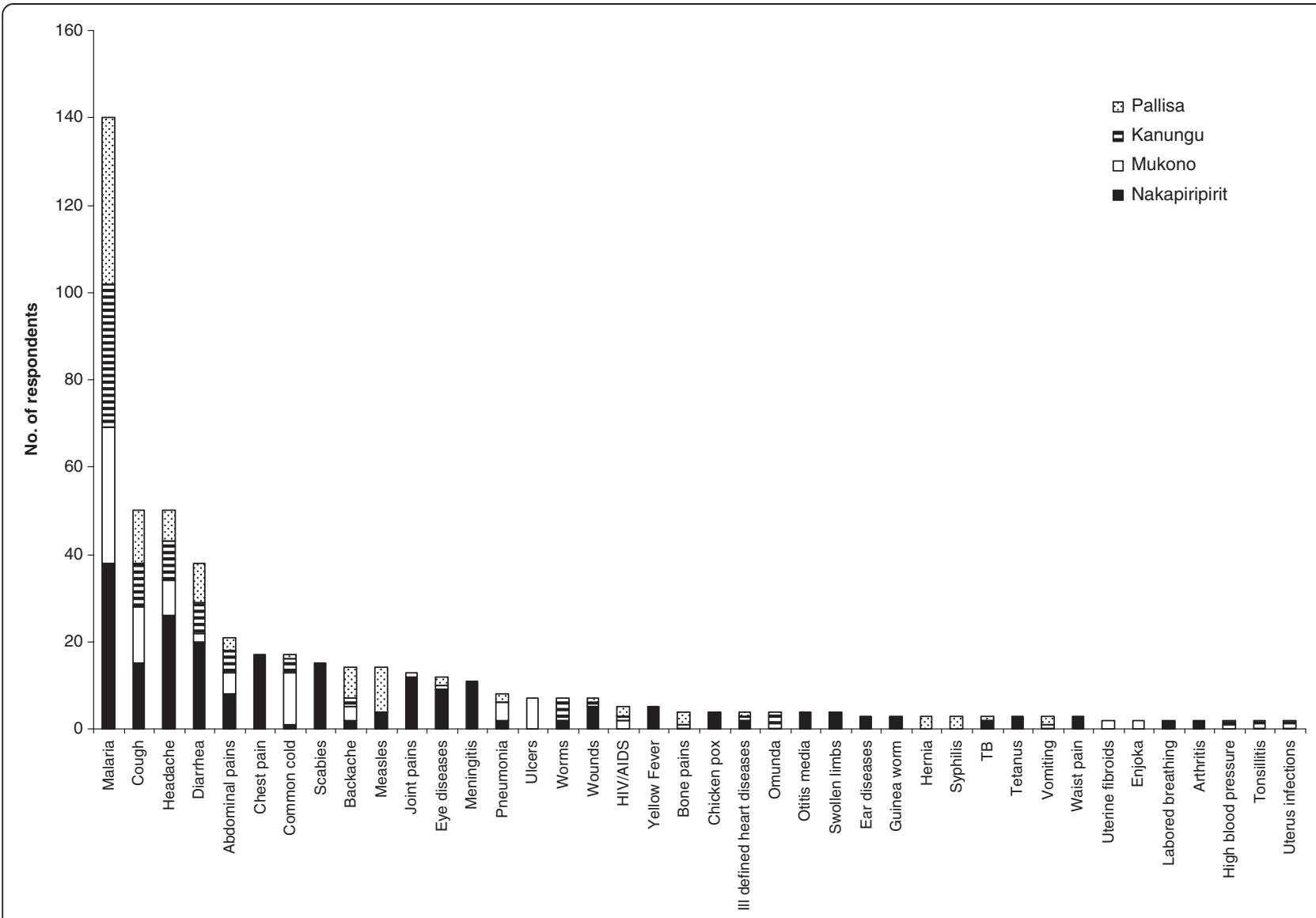

Figure 2 Most frequently mentioned ailments by respondents of Nakapiripirit, Mukono, Kanungu and Pallisa. Included are diseases mentioned by two or more respondents.

The plant species used to treat ailments in the home were documented in household interviews using a questionnaire modified from that used by Almeida et al. [18]. To select respondents to participate in the interviews one village was selected serendipitously from each district. In each chosen village between 40 and 50 households were selected by simple random sampling. Interviews with children were conducted at one of the primary school in each of the villages. Ten pupils attending classes between primary 4 and 7 , and equally distributed in gender were identified by the head teacher for the interviews. Altogether we interviewed 171 respondents (93 female and 78 male).

Our interviews centered on the following types of information: Common ailments that afflict households; form of health care sought by community members; specific ailments for which people seek health care from TMPs; materials used to treat ailments in traditional medicine; how the materials are used to treat ailments; and perceptions of efficacy.

In order to prioritize among the widely diverse herbal medicine plant species we conducted a Rapid Market
Survey to determine the most important medicinal plants. According to Cunningham [19], highly valued species routinely appear in markets. We interviewed 20 market vendors of Owino market specialized in the sale of traditional medicines. Owino market is the largest market in Uganda. Vendors were requested to, among other things, name and rank the most valuable medicinal species. Species mentioned in all interviews were collected and identified with the help of a parataxonomist, and archived at Makerere University Herbarium (MHU). Species were identified using the Flora for Tropical Africa. Species names were verified by making reference to the IPNI (International Plant Names Index; www.ipni.org).

Permission to conduct this study was sought for and granted by the Uganda National Council for Science and Technology (SS 2163). In every village we requested for and acquired an endorsement to conduct the study by the local village politicians. Before every interview, the purpose, method and end use for the data collected were explained to every respondent before requesting for permission to interview the respondent. 

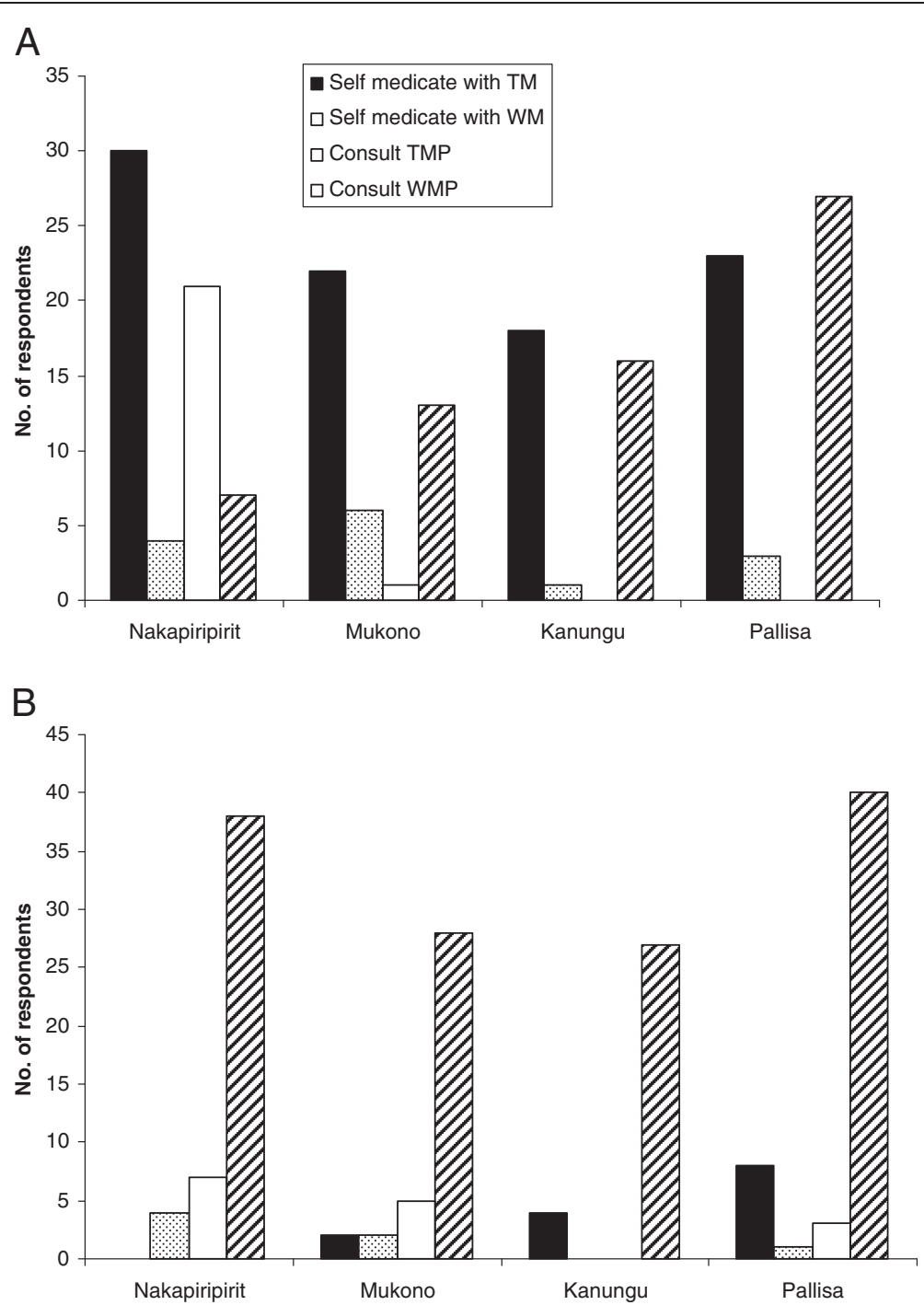

Figure 3 Health seeking behaviors of respondents in Nakapiripirit, Mukono, Kanungu and Pallisa. $\mathbf{a}$. first form of health care sought. $\mathbf{b}$ secondary form of care sought when the first provider or source fails to work.

\section{Data analysis}

All questionnaire data was entered into Microsoft ${ }^{\circledR}$ Office Excel and later imported into SPSS 12.0.1 for Windows, for analysis. Frequencies were summarized and percentages calculated from the data. Chi-square was computed to detect associations between the tribe and sex as independent variables and number of remedies as the dependent variable. A Pearson correlation coefficient was computed to detect the association between age and number of remedies. The number of ailments that a respondent knew how to treat was equated to richness of IK. We also calculated the informant consensus factor (ICF) to determine the disease systems where there was highest consensus on plants used in treatments. A high consensus factor (close to 1) means that the community is confident in the choice of plants, whereas a low ICF (close to 0) means that the community is still experimenting and that the treatments may not be effective [20]. Disease systems with 2 or fewer respondents were not considered when performing the ICF analysis. The ICF is calculated using the expression:

$$
I C F=\frac{N_{u r}-T}{N_{u r}-1}
$$

Whereby $\mathrm{N}_{\mathrm{ur}}$ represents the number of respondents mentioning a disease and, ' $\mathrm{T}$ ' the number of plant species mentioned for the disease. 
Table 2 Other material used in treatments

\begin{tabular}{ll}
\hline Material & Ailment \\
\hline 1.White chalk soil & Chicken pox \\
2.Animal parts (fat, offal, blood, & Chest pain \\
a.Milk from a black cow & \\
b.fat & Measles \\
3.Ash & Tuberculosis \\
& Febrile convulsions, \\
4.Coral salt, Ebalangit & Wounds, Malaria \\
5.Hot cloth & Toothache \\
6.Petroleum Jelly & Headache \\
7.Kihonde & Pneumonia, Fractures \\
8.Kitchen soot & \\
9.Rabbit hair and parts of the & \\
animal called Napupu & Worms \\
10.Salt and Rock salt & Burns \\
11.Anthill soil & \\
12.Soil, Red soil, & Wounds \\
& Pyomyositis \\
13.Water from a grass roof & Diarrhea, Tonsillitis, \\
\hline
\end{tabular}

\section{Results}

\section{Respondent characteristics}

The respondents interviewed in this study had attained low levels of formal education (Table 1): the majority had attained no higher than primary level education (57\%), and 23\% had not attained any formal education. Most respondents were Christians (> 90\%). The respondents mostly belonged to the tribes Ngakarimojong, Bakiga, Bagwere and Baganda. Their livelihoods occupations were crop farming. Others, especially those from Nakapiripirit District, were not employed in wage labor.

\section{Indigenous knowledge of traditional medicine use}

In this study the common diseases afflicting people in the four study districts include malaria, cough, headache, diarrhea, abdominal pain, flu, back-ache and eye diseases (Figure 2). When people fall sick they either selfmedicate using traditional medicines or consult western medicine practitioners (Figure 3a). Nakapiripirit is unique in this regard, because people either self medicate using traditional medicine (TM) or consult traditional medicine practitioners (TMPs). In all the studied districts, when the first form of care sought does not yield positive outcomes, people will consult western medicine practitioners (Figure $3 \mathrm{~b}$ ).

Respondents use plants to prepare TM therapies. They infrequently add animal products, inorganic materials e.g. soil, kitchen soot and water (Table 2). The treatments are not accompanied with any rituals. On average every respondent knows how to treat at least three ailments using herbal medicines. Leaves are the most commonly used plant organ for the preparation of herbal medicines; roots and stems are also commonly used (Figure 4). The medicines are mostly prepared as water extracts or as decoctions and administered orally (Figure 5). Herbal medicines are stored in plastic bottles (Figure 6), and according to one respondent, it is only medicines prepared from difficult to find species that are stored; easy to find species are not. Medicines when stored last for short periods of time (Figure 7).

We documented 262 plants used to treat 78 diseases and medical conditions (Table 3). 151 of these have been identified to species level. The rest of the species could not be identified because we failed to collect voucher specimens due to the prevailing insecurity in Nakapiripirit at the time this study was conducted. Nine plants, although unidentified have been included in the list because they were mentioned by three or more

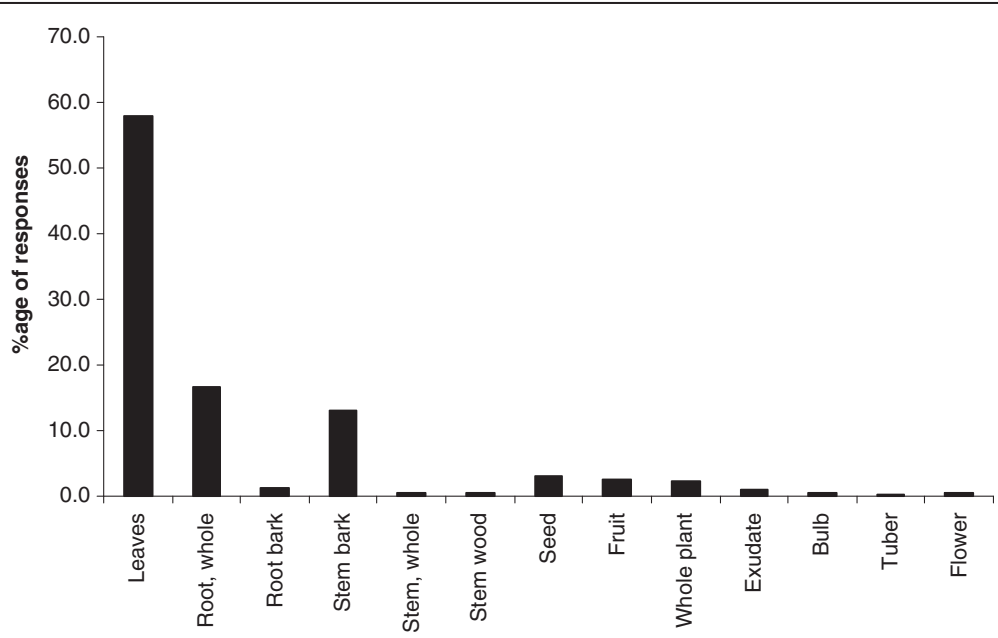

Figure 4 Plants parts used in the preparation of herbal medicines. 


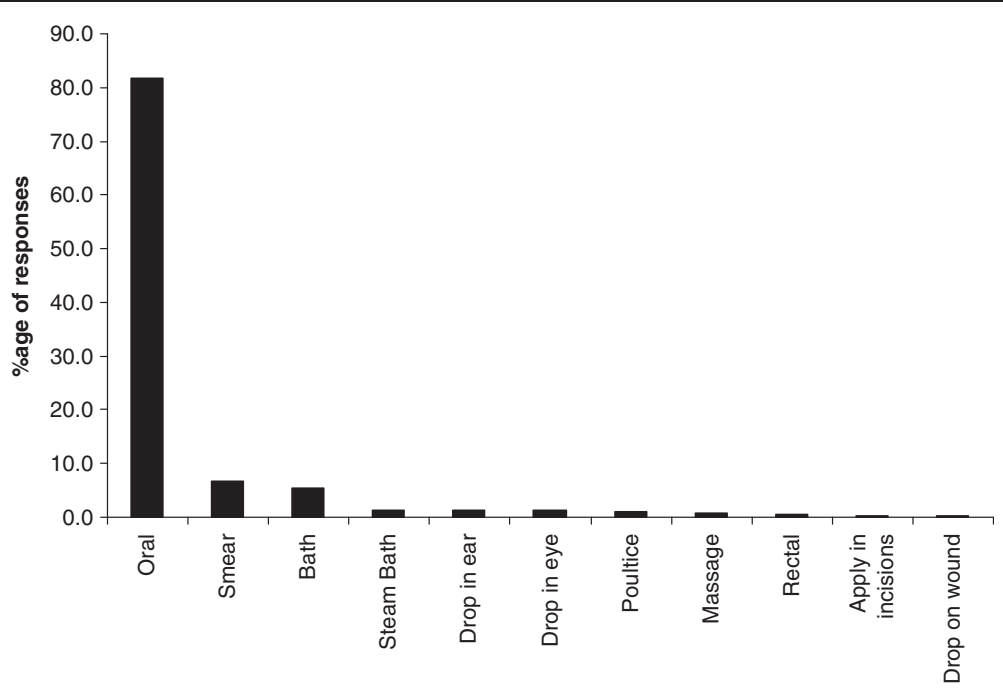

Figure 5 Routes of administration of traditional medicines.

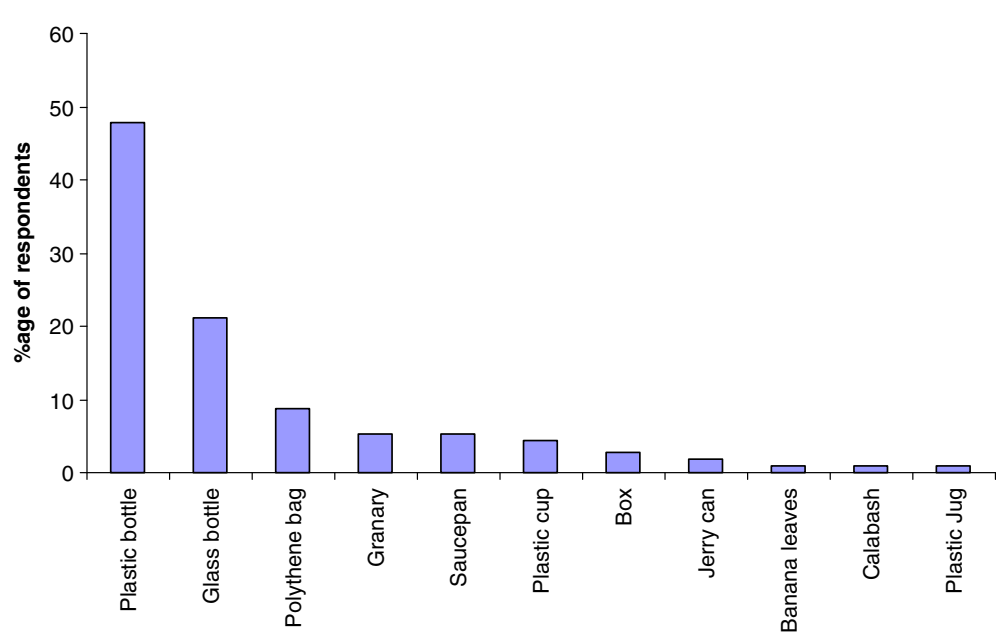

Figure 6 Storage practices of herbal medicines by respondents.

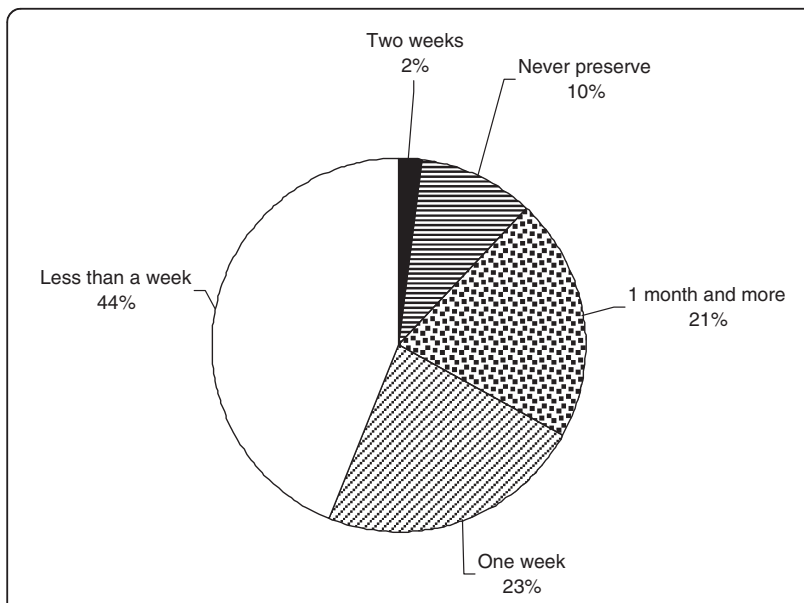

Figure 7 Period of storage of herbal medicines before they get spoiled. respondents. 44 of the species have been prioritized here on the basis of being known to treat four or more diseases/conditions (Additional file 1: Table S1). The species used to treat ailments varied among the study communities (data not shown), with the Nakapiripirit respondents mentioned the most disparate species.

The informant consensus factor (ICF) was highest for meningitis, scabies, enjoka ${ }^{a}$, snake bite, malaria, uterus infection, diarrhea, wounds, cough, headache, measles, fever, abdominal pain, common cold, worms and yellow fever (Table 4). The high ICF for these ailments suggests that the herbal medicines used to treat them are potentially efficacious. This analysis is well collaborated by observations reported by respondents on efficacy. That is to say five or more respondents reported that treatments for malaria, cough, headache, abdominal pain, diarrhea and meningitis were efficacious (Table 5). 
Table 3 Species mentioned in interviews, their families and frequency of mention by respondents

\begin{tabular}{|c|c|c|}
\hline Species & Family & Freq. \\
\hline Vernonia amygdalina Delile & Asteraceae & 82 \\
\hline Aloe sp. & Aloaceae & 37 \\
\hline Azadirachta indica A. Juss. & Meliaceae & 30 \\
\hline Cassia nigricans Vahl. & Caesalpiniaceae & 24 \\
\hline Mangifera indica $\mathrm{L}$. & Anacardiaceae & 22 \\
\hline Carica papaya L. & Caricaceae & 16 \\
\hline Momordica foetida Schumach. & Cucurbitaceae & 15 \\
\hline Chasmanthera dependens Hochst. & Menispermaceae & 11 \\
\hline Acacia nilotica (L.) Willd. ex Delile & Mimosaceae & 10 \\
\hline Psidium guajava $\mathrm{L}$. & Myrtaceae & 9 \\
\hline Senna occidentalis (L.) Link & Caesalpiniaceae & 9 \\
\hline Warburgia salutaris (G. Bertol.) Chiov. & Canellaceae & 9 \\
\hline Bidens pilosa $\mathrm{L}$. & Asteraceae & 8 \\
\hline Physalis peruviana $\mathrm{L}$. & Solanaceae & 8 \\
\hline Vernonia lasiopus O. Hoffm. & Asteraceae & 8 \\
\hline Albizia anthelmintica Brongn. & Mimosaceae & 7 \\
\hline Carissa edulis (Forssk.) Vahl. & Apocynaceae & 7 \\
\hline Abrus precatorius L. & Papilionaceae & 6 \\
\hline Aristolochia elegans Mast. & Aristolochiaceae & 6 \\
\hline Dracaena steudneri Engl. & Dracaenaceae & 6 \\
\hline Lantana camara L. & Verbenaceae & 6 \\
\hline Plectranthus barbatus Andr. & Lamiaceae & 6 \\
\hline Bothriocline longipes (Oliv. \& Hiern) N. E. Br. & Asteraceae & 5 \\
\hline Callistemon citrinus (Curt.) Stapf. & Myrtaceae & 5 \\
\hline Citrus sinensis (L.) Osbeck & Rutaceae & 5 \\
\hline Conyza sumatrensis (Retz.) E. Walker & Asteraceae & 5 \\
\hline Crassocephalum crepidioides (Benth.) S.Moore & Asteraceae & 5 \\
\hline Cymbopogon nardus (L.) Rendle & Poaceae & 5 \\
\hline Indigofera arrecta Hochst. & Papilionaceae & 5 \\
\hline Lantana trifolia L. & Verbenaceae & 5 \\
\hline Ocimum gratissimum $\mathrm{L}$. & Lamiaceae & 5 \\
\hline Sida acuta Burm. f. & Malvaceae & 5 \\
\hline Zanthoxylum leprieurii Guill. \& Perr. & Rutaceae & 5 \\
\hline Cupressus lusitanica Mill. & Cupressaceae & 4 \\
\hline Digitaria abyssinica (A. Rich.) Stapf & Poaceae & 4 \\
\hline Erythrina abyssinica Lam. & Papilionaceae & 4 \\
\hline Eucalyptus spp. & Myrtaceae & 4 \\
\hline Euphorbia tirucalli L. & Euphorbiaceae & 4 \\
\hline Jatropha curcas L. & Euphorbiaceae & 4 \\
\hline Leonotis nepetifolia (L.) R. Br. & Lamiaceae & 4 \\
\hline Nicotiana tabacum L. & Solanaceae & 4 \\
\hline Persea americana Mill. & Lauraceae & 4 \\
\hline Saba comorensis (Boj) Pich. & Apocynaceae & 4 \\
\hline Tagetes minuta $\mathrm{L}$. & Asteraceae & 4 \\
\hline
\end{tabular}


Table 3 Species mentioned in interviews, their families and frequency of mention by respondents (Continued)

\begin{tabular}{|c|c|c|}
\hline Zizyphus mauritiana Lam. & Rhamnaceae & 4 \\
\hline Acacia abyssinica Hochst. ex Benth. & Mimosaceae & 3 \\
\hline Acacia oerfota (Forssk.) Schweinf. & Mimosaceae & 3 \\
\hline Albizia coriaria Welw. ex Oliv. & Mimosaceae & 3 \\
\hline Allium cepa $\mathrm{L}$. & Alliaceae & 3 \\
\hline Euphorbia sp. & Euphorbiaceae & 3 \\
\hline Ficus natalensis Hochst. & Moraceae & 3 \\
\hline Indigofera garckeana Vatke & Papilionaceae & 3 \\
\hline Kigelia africana (Lam.) Benth. & Bignoniaceae & 3 \\
\hline Melia azedarach Linn. & Meliaceae & 3 \\
\hline Musa acuminata Colla & Musaceae & 3 \\
\hline Sarcocephalus latifolius (Smith) Bruce & Rubiaceae & 3 \\
\hline Triumfetta rhomboidea Jacq. & Tiliaceae & 3 \\
\hline Acacia mellifera (Vahl) Benth & Mimosaceae & 2 \\
\hline Acacia spirocarpa Hochst. ex A. Rich. & Mimosaceae & 2 \\
\hline Ageratum conyzoides $\mathrm{L}$. & Asteraceae & 2 \\
\hline Artocarpus heterophyllus Lam. & Moraceae & 2 \\
\hline Aspilia mossambicensis (Oliv.) Wild & Asteraceae & 2 \\
\hline Canarium schweinfurthii Engl. & Burseraceae & 2 \\
\hline Cardiospermum halicacabum L. & Sapindaceae & 2 \\
\hline Chenopodium opulifolium Schrad. ex Koch \& Ziz & Chenopodiaceae & 2 \\
\hline Cissampelos mucronata A.Rich. & Menispermaceae & 2 \\
\hline Citrus limon (L.) Burm.f. & Rutaceae & 2 \\
\hline Coffea canephora Pierre ex A. Froehner & Rubiaceae & 2 \\
\hline Commiphora africana (A. Rich.) Engl. & Burseraceae & 2 \\
\hline Cynodon spp. & Poaceae & 2 \\
\hline Emilia coccinea (Sims) G. Don & Asteraceae & 2 \\
\hline Euphorbia heterophylla L. & Euphorbiaceae & 2 \\
\hline Galinsoga parviflora Cav. & Asteraceae & 2 \\
\hline Gouania longispicata Engl. & Rhamnaceae & 2 \\
\hline Hibiscus fuscus Garcke & Malvaceae & 2 \\
\hline Hoslundia opposita Vahl & Lamiaceae & 2 \\
\hline Imperata cylindrica (L.) P.Beauv. & Poaceae & 2 \\
\hline Lagenaria sphaerica (Sond.) Naud. & Cucurbitaceae & 2 \\
\hline Manihot esculenta Crantz & Euphorbiaceae & 2 \\
\hline Mollugo cerviana (L.) Ser. & Molluginaceae & 2 \\
\hline Mollugo nudicaulis Lam. & Molluginaceae & 2 \\
\hline Moringa oleifera Lam. & Moringaceae & 2 \\
\hline Ocimum lamiifolium Benth. & Lamiaceae & 2 \\
\hline Phyllanthus guineensis Pax & Euphorbiaceae & 2 \\
\hline Sesamum indicum $\mathrm{L}$. & Pedaliaceae & 2 \\
\hline Sesbania sesban (L.) Merr. & Papilionaceae & 2 \\
\hline Solanum giganteum Jacq. & Solanaceae & 2 \\
\hline Solanum incanum L. & Solanaceae & 2 \\
\hline Solanum lycopersicum L. & Solanaceae & 2 \\
\hline
\end{tabular}


Table 3 Species mentioned in interviews, their families and frequency of mention by respondents (Continued)

\begin{tabular}{|c|c|c|}
\hline Sphaeranthus suaveolens DC. & Asteraceae & 2 \\
\hline Syzygium cumini (L.) Skeels & Myrtaceae & 2 \\
\hline Terminalia brownii Fres. & Combretaceae & 2 \\
\hline Tetradenia riparia (Hochst.) Codd & Lamiaceae & 2 \\
\hline Ximenia americana $\mathrm{L}$. & Olacaceae & 2 \\
\hline Zingiber officinale Roscoe & Zingiberaceae & 2 \\
\hline Acacia mearnsii De Wild. & Mimosaceae & 1 \\
\hline Acacia polyacantha Willd. & Mimosaceae & 1 \\
\hline Acacia sp. & Mimosaceae & 1 \\
\hline Achyranthes aspera L. & Amaranthaceae & 1 \\
\hline Albizia gummifera (J.F. Gmel.) C.A.Sm. & Mimosaceae & 1 \\
\hline Alstonia boonei De Wild. & Apocynaceae & 1 \\
\hline Asparagus racemosus Willd. & Asparagaceae & 1 \\
\hline Balanites aegyptiacus (L.) Delile & Balanitaceae & 1 \\
\hline Blumea alata (D.Don) DC. & Asteraceae & 1 \\
\hline Bridelia micrantha (Hochst.) Baill. & Euphorbiaceae & 1 \\
\hline Cajanus cajan (L.) Millsp. & Papilionaceae & 1 \\
\hline Cannabis sativa $\mathrm{L}$. & Cannabinaceae & 1 \\
\hline Cleome gynandra L. & Capparaceae & 1 \\
\hline Clerodendrum rotundifolium Oliv. & Verbenaceae & 1 \\
\hline Combretum collinum Fresen. & Combretaceae & 1 \\
\hline Commelina africana $\mathrm{L}$. & Commelinaceae & 1 \\
\hline Cucurbita pepo L. & Cucurbitaceae & 1 \\
\hline Cyphostemma cyphopetalum (Fresen.) Desc. Ex Wild \& Drumm. & Vitaceae & 1 \\
\hline Desmodium adscendens (Sw.) DC. & Papilionaceae & 1 \\
\hline Dicrocephala integrifolia (L.f.) O. Kuntze & Asteraceae & 1 \\
\hline Erythrococca bongensis Pax & Euphorbiaceae & 1 \\
\hline Ficus asperifolia Miq. & Moraceae & 1 \\
\hline Ficus saussureana DC. & Moraceae & 1 \\
\hline Gutenbergia cordifolia Benth. ex Oliv & Asteraceae & 1 \\
\hline Hyptis suaveolens (L.) Poit. & Lamiaceae & 1 \\
\hline Ipomoea batatas (L.) Lam. & Convolvulaceae & 1 \\
\hline Justicia betonica L. & Acanthaceae & 1 \\
\hline Kalanchoe densiflora Rolfe & Crassulaceae & 1 \\
\hline Markhamia lutea (Benth.) K. Schum. & Bignoniaceae & 1 \\
\hline Melinis repens (Willd.) Zizka & Poaceae & 1 \\
\hline Melothria punctata Cogniaux & Cucurbitaceae & 1 \\
\hline Microglossa pyrifolia (Lam.) O. Ktze. & Asteraceae & 1 \\
\hline Myrica salicifolia Hochst. Ex A. Rich. & Myricaceae & 1 \\
\hline Ocimum basilicum L. & Lamiaceae & 1 \\
\hline Oxalis corniculata L. & Oxalidaceae & 1 \\
\hline Oxygonum sinuatum (Meisn.) Dammer & Polygonaceae & 1 \\
\hline Passiflora edulis Sims & Passifloraceae & 1 \\
\hline Pennisetum purpureum K. Schumach. & Poaceae & 1 \\
\hline Phytolacca dodecandra L'Her. & Phytolaccaceae & 1 \\
\hline
\end{tabular}


Table 3 Species mentioned in interviews, their families and frequency of mention by respondents (Continued)

\begin{tabular}{|c|c|c|}
\hline Portulaca quadrifida L. & Portulacaceae & 1 \\
\hline Priva cordifolia Druce & Verbenaceae & 1 \\
\hline Rhus vulgaris Meikle & Anacardiaceae & 1 \\
\hline Rumex usambarensis (Dammer) Dammer & Polygonaceae & 1 \\
\hline Rytigynia spp. & Rubiaceae & 1 \\
\hline Saccharum officinarum L. & Poaceae & 1 \\
\hline Senna didymobotrya (Frisen.) Irwin \& Barneby & Caesalpiniaceae & 1 \\
\hline Senna siamea (Lam.) H.S. Irwin \& Barneby & Caesalpiniaceae & 1 \\
\hline Sida cuneifolia Roxb. & Malvaceae & 1 \\
\hline Solanum aculeastrum Dunal & Solanaceae & 1 \\
\hline Solanum aethiopicum L. & Solanaceae & 1 \\
\hline Steganotaenia araliacea Hochst. & Apiaceae & 1 \\
\hline Tephrosia vogelii Hook. f. & Papilionaceae & 1 \\
\hline Thunbergia alata Bojer ex Sims & Acanthaceae & 1 \\
\hline Vigna unguiculata (L.) Walp. & Papilionaceae & 1 \\
\hline Vitex fischeri Gurke & Verbenaceae & 1 \\
\hline Zehneria scabra (L.f.) Soud. & Cucurbitaceae & 1 \\
\hline Unidentified (Tadeo) & & 5 \\
\hline Unidentified (Eyoroit) & & 4 \\
\hline Unidentified (Musuku) & & 4 \\
\hline Unidentified (Nalongo) & & 3 \\
\hline Unidentified (Ethiokan) & & 3 \\
\hline Unidentified (Etabataba) & & 3 \\
\hline
\end{tabular}

Apart from a few species mentioned by three or more people, only identified species are shown.

Table 4 Informant consensus factor for diseases by respondents from Nakapiripirit, Pallisa, Kanungu, and Mukono

\begin{tabular}{ll}
\hline Disease & ICF \\
\hline Meningitis & 0.92 \\
Scabies & 0.92 \\
Enjoka & 0.88 \\
Snake bite & 0.80 \\
Malaria & 0.76 \\
Uterus infection & 0.75 \\
Diarrhea & 0.68 \\
Wounds & 0.67 \\
Cough & 0.55 \\
Headache & 0.54 \\
Measles & 0.50 \\
Fever & 0.50 \\
Abdominal pain & 0.38 \\
Flu & 0.38 \\
Worms & 0.33 \\
Yellow fever & 0.33 \\
\hline Oly disease where &
\end{tabular}

Only disease where 3 or more respondents mentioned herbal medicines are reported here.
The knowledge to treat ailments is acquired from a variety of sources by respondents, the most important of these being parents and grandparents (Figure 8). Gender does not seem to affect level of IK associated with herbal medicine in this study (chi-sq $=3.508, \mathrm{p}>0.05)$. Age and tribe, on the other hand, affect the level of knowledge. Older people mentioned more herbal remedies than younger people $(\mathrm{r}=0.2, \mathrm{p}<0.05)$. The people of Nakapiripirit, the Ngakarimojong, mentioned more remedies than respondents from other ethnic groups (up to six compared to three from other ethnic groups).

A survey of medicinal plants sold by market vendors revealed that most of the medicinal species mentioned in interviews in this survey were not sold in the market. Table 6 shows 35 species encountered in markets and which were mentioned by three or more respondents. Of the 35 species, only 11 appear in the medicinal plants inventory reported here.

\section{Discussion}

Respondents interviewed in this survey have knowledge to treat 78 ailments and conditions. Herbal medicine knowledge is extensive as every respondent can, on average, mention three remedies. However, this knowledge 
Table 5 Perceptions on the efficacy of herbal medicines for the treatment of different diseases

\begin{tabular}{|c|c|c|c|c|c|}
\hline Disease & Improved & Recovered & some times Recovered & Did not improve & Total \\
\hline Malaria & 24 & 26 & 1 & 1 & 52 \\
\hline Cough & 7 & 9 & & & 16 \\
\hline Headache & 2 & 5 & & & 7 \\
\hline Abdominal pain & 1 & 5 & & & 6 \\
\hline Diarrhea & 3 & 2 & & & 5 \\
\hline Meningitis & 2 & 3 & & & 5 \\
\hline Flu & 1 & 2 & & 1 & 4 \\
\hline Abdominal worms & & 4 & & & 4 \\
\hline Joint pains & 2 & 1 & & & 3 \\
\hline Dysentery & 2 & & & & 2 \\
\hline Pneumonia & 1 & 1 & & & 2 \\
\hline Measles & 1 & 1 & & & 2 \\
\hline Ulcer & & 2 & & & 2 \\
\hline Yellow fever & 1 & 1 & & & 2 \\
\hline Anemia & & 1 & & & 1 \\
\hline Chest pain & 1 & & & & 1 \\
\hline Pyomystis & & 1 & & & 1 \\
\hline Fever & & & & 1 & 1 \\
\hline Gastritis & & 1 & & & 1 \\
\hline Headache & 1 & & & & 1 \\
\hline Lameness & & 1 & & & 1 \\
\hline Malnutrition in children & & 1 & & & 1 \\
\hline Nkadomo & 1 & & & & 1 \\
\hline Obulogo & & 1 & & & 1 \\
\hline Omunda & 1 & & & & 1 \\
\hline Uterus infection & & 1 & & & 1 \\
\hline Vomiting & & 1 & & & 1 \\
\hline Waist pain & 1 & & & & 1 \\
\hline Whitlow & & 1 & & & 1 \\
\hline
\end{tabular}

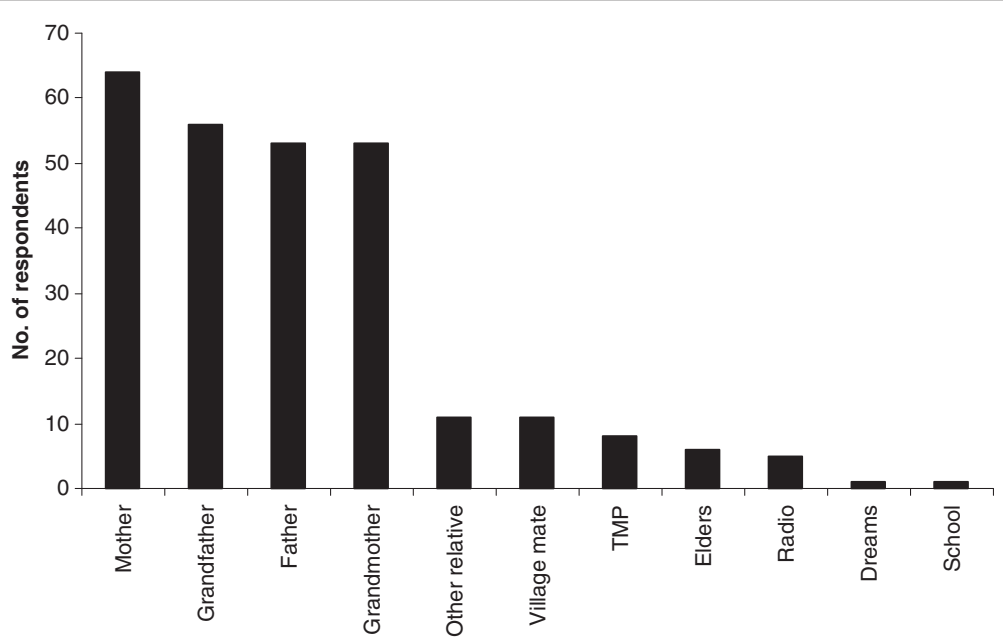

Figure 8 Source of knowledge on how to use plants for healing. Other relatives reported in the study are aunties and brother. 
Table 6 The most frequently sold herbal medicine species by vendors of Owino market

\begin{tabular}{|c|c|c|}
\hline Species & Local name & Mean Rank \\
\hline Unidentified & Dokiyo & 1.0 \\
\hline Warburgia salutaris (G. Bertol.) Chiov. & Abasi & 1.7 \\
\hline Unidentified & Mbaluka & 1.9 \\
\hline Securidaca longipedunculata Fres. & Mukondwe & 2.0 \\
\hline Mangifera indica $\mathrm{L}$. & Muyembe & 2.3 \\
\hline Zanthoxylum chalybeum Engl. & Ntale ya dungu & 2.3 \\
\hline Psorospermum febrifugum Spach & Kanzironziro & 2.4 \\
\hline Alstonia boonei De Wild. & Mubaja ngalabi & 2.5 \\
\hline Piliostigma thonningii & Mugaali & 2.7 \\
\hline \multicolumn{3}{|l|}{ (Schumach.) Milne-Redh. } \\
\hline Garcinia buchananii Baker & Musaali & 3.2 \\
\hline Vernonia amygdalina Delile & Mululuza & 3.3 \\
\hline Ziziphus pubescens Oliver & Mugenda kilo & 3.4 \\
\hline Entada abyssinica A.Rich. & Mwolola & 3.5 \\
\hline Albizia coriaria Welw. ex Oliv. & Mugavu & 3.9 \\
\hline Myrica kandtiana Engl. & Kikimbo & 4.0 \\
\hline Acacia polyacantha Willd. & Kibeere & 4.2 \\
\hline Syzygium cumini (L.) Skeels & Jambula & 4.3 \\
\hline Toddalia asiatica (L.) Lam. & Kawule & 4.3 \\
\hline Acacia hockii De Wild. & Kasaana & 4.5 \\
\hline Aristolochia elegans Mast. & Musuja welaba & 4.8 \\
\hline Zanthoxylum spp. & Munyeeye & 4.9 \\
\hline Erythrina abyssinica Lam. & Jirikiti & 5.0 \\
\hline Rhus vulgaris Meikle & Kakwanso kwanso & 5.1 \\
\hline Prunus africana (Hook.f.) Kalkman & Ntaseesa & 5.1 \\
\hline Spathodea campanulata P. Beauv. & Kifabakazi & 5.1 \\
\hline Canarium schweinfurthii Engl. & Muwafu & 5.1 \\
\hline Carissa edulis (Forssk.) Vahl. & Muyonza & 5.3 \\
\hline $\begin{array}{l}\text { Piptadeniastrum africanum (Hook.f.) } \\
\text { Brenan }\end{array}$ & Mpewere & 5.4 \\
\hline Unidentified & Naligwalimu & 5.4 \\
\hline Cryptolepis sanguinolenta (lindl.) Schltr. & Kafulu & 5.8 \\
\hline Kigelia africana (Lam.) Benth. & Mussa & 6.3 \\
\hline Combretum molle G.Don & Ndagi & 6.5 \\
\hline Unidentified & Muwo & 6.7 \\
\hline Dracaena steudneri Engl. & Kajjolyenjovu & 7.7 \\
\hline Albizia spp. & Nongo & 8.3 \\
\hline
\end{tabular}

Mean ranks are also shown. A rank of 1 shows a species known to be the most important and 8 the least important among the sold species. Only species mentioned by 3 or more vendors are shown. Species mentioned by respondents in household interviews are highlighted.

varied from district to district. It was not possible to do a complete review of the ethnomedicinal uses of the species reported here. However, and at least for the species reported here as being the most commonly used to treat malaria, similar therapeutic claims have been reported from other parts of the world (Table 7). Furthermore, for some of the species like Azadirachta indica antiplasmodial activity has also been demonstrated in vivo and in vitro [21]. The similar use of a plant species for the treatment of the same ailment (like malaria in this case) in different regions of the world is one form of evidence that the species in question may be efficacious and also safe to use $[22,23]$. For the species shown in Table 7, therefore, there appears to be evidence that the species are effective in treating malaria.

In this study respondents were seen to self medicate using plants and allopathic medicines. Herbal medicines are frequently used in self medication to alleviate symptoms or shorten recovery time in self limiting ailments ${ }^{\mathrm{b}}$ [22], such as malaria and diarrhea. On the other hand, allopathic medicine is preferred for the treatment of serious diseases and conditions like tuberculosis.

The practice of self-medication is popular in many parts of the world including Africa where the health infrastructure is poor, or where people have a negative attitude about the quality of care in medical facilities, or people can ill afford the consultation fees charged in medical facilities $[13,24,25]$. Respondents in this study stated that TMPs are not usually consulted (except in Nakapiripirit the most marginalized of the study districts). According to Tabuti et al. [3], TMPs are commonly consulted for chronic and difficult to understand ailment. The implications of poor patronage of TMP may be a faster loss of IK associated with TM.

Knowledge of how to treat ailments by respondents is acquired from parents and grandparents. Indeed older people mention significantly more remedies than the young. This is in agreement with studies conducted elsewhere which show that older people have more IK than younger ones and that they are the ones who transmit this knowledge [9].

\section{Conclusions and recommendations}

This survey has indicated that abundant indigenous knowledge on traditional medicine (TM) still exists and that TM is still important in Uganda, because respondents mentioned many species and remedies used in traditional medicine and stated that they use it as a first line of health care when they fall sick. The patronage of TMPs in this study appears to be low. This is somewhat confusing given the reportedly important role that TMPs play in TM [4]. More rigorous health seeking behavior studies should be conducted to clarify this important aspect of TM.

There is need to validate the efficacy and safety of the remedies reported in this study to determine whether they are effective to treat the diseases that they are claimed to treat and are safe to use. Priority species 
Table 7 Comparative ethnomedicinal use for the treatment of malaria in other studies and reports of antiplasmodial activity

\begin{tabular}{|c|c|}
\hline Species & Reference \\
\hline $\begin{array}{l}\text { Vernonia } \\
\text { amygdalina }\end{array}$ & [26], references in [26], [27]. Antiplasmodial activity is reported by Tona et al. [28] \\
\hline Aloe spp. & {$[29],[27]$} \\
\hline $\begin{array}{l}\text { Azadirachta } \\
\text { indica }\end{array}$ & $\begin{array}{l}\text { [26], references in [26]. Antiplasmodial activity is reported in references by Nguta et al. [29] and Sofowora [21], and in a review by } \\
\text { Soh and Benoit-Vical [30], [27] }\end{array}$ \\
\hline Mangifera indica & [26], references in [26], [29] \\
\hline
\end{tabular}

should be those that are used to treat diseases that respondents have observed to be effective and for which people have the highest agreement measured as informant consensus factor (ICF) such as meningitis (Additional file 1: Table S1). The first step in this direction should be to conduct a literature review to see what information exists for the target species before bioassays are conducted in the laboratory.

Secondly, this study was conducted in only four districts of Uganda, and showed that IK varied between districts. This means that more detailed surveys covering the whole country remain to be undertaken to complete the documentation of this knowledge in Uganda. Thirdly, a wider market survey of medicinal plants needs to be conducted to capture the whole diversity of herbal medicine species sold in markets.

\section{Endnotes}

${ }^{a}$ Enjoka is an all inclusive term that may refer to abdominal worms. It may also mean abdominal cramps/ pain which are believed to be caused by worms among other things; gonorrhea; or painful menses in females

${ }^{\mathrm{b}}$ Self limiting ailments are disease conditions whose symptoms may disappear even without treatment

\section{Additional file}

Additional file 1: Table S1. The most commonly used herbal medicine plants and the diseases that they treat.

\section{Competing interests}

The authors declare that they have no competing interests.

\section{Authors' contributions}

JRST and DK conceived the study, and participated in its design and coordination. All authors helped to draft the manuscript, read and approve the final manuscript.

\section{Acknowledgments}

We are very grateful to the respondents who participated in this survey. This project was financed by the Uganda National Commission for UNESCO (UNATCOM). Makerere University provided additional support. Permission to conduct this study was granted by the Uganda National Council for Science and Technology (SS 2163). We are also grateful to our assistants Mr. Henry Wafula, Mr. Ayub Mukisa and Mr. Experito Kakooza.
Author details

${ }^{1}$ Makerere University, College of Agricultural and Environmental Sciences (MUCAES), P.O. Box 7062, Kampala, Uganda. ${ }^{2}$ Department of Botany, Herbarium and Botanic Garden, Makerere University, P. O. Box 7062, Kampala, Uganda. ${ }^{3}$ Uganda National Commission for UNESCO, Ministry of Education \& Sports, Embassy House, King George VI Way, Kampala, Uganda. ${ }^{4}$ World Health Organization, WHO Regional Office for Africa, P.O. Box 6, Brazzaville, Republic of Congo.

Received: 30 March 2012 Accepted: 4 July 2012

Published: 3 September 2012

\section{References}

1. Bannernman R: Traditional Medicine and Health Care Coverage. In The role of traditional medicine in primary health care. Edited by Bannerman $\mathrm{R}$, Burton J, Wen-Chieh C. Geneva: World Health Organization; 1983:318-327.

2. WHO: WHO Traditional Medicine Strategy 2002-2005. Geneva: World Health Organization; 2002.

3. Tabuti JRS, Dhillion SS, Lye KA: Traditional medicine in Bulamogi county, Uganda: its practitioners, users and viability. J Ethnopharmacol 2003, 85(1):119-129.

4. World Health Organization and UNICEF: World Health Organization: Primary Health Care: Report of the International Conference on Primary Health Care. Alma-Ata USSR. 62 September, 1978. Geneva: WHO; 1978.

5. Cox PA: Will tribal knowledge survive the millennium? Science 2000 , 287:44-45.

6. World Bank: World Development Report 1992: Development and the environment. Washington, D.C: The World Bank; 1992.

7. Obbo C: Healing: cultural fundamentalism and syncreticism in Buganda. Africa 1996, 66(2):183-201.

8. Hafeel A, Tagdur S, Payyappapallimana U, Shankar D: Participatory rapid assessment of local health traditions. COMPAS Magazine 2001, 4:17-19.

9. Millar D, Haverkort B: African Knowledge and Sciences: Understanding and supporting the ways of knowing in Sub-Saharan Africa. In African knowledges and sciences: Exploring the ways of knowing in Sub-Saharan Africa. Edited by Millar D, Kendie SB, Apusigah AA, Haverkort B. Bolgatanga U/R Region, Ghana: COMPAS/CTA/UDS; 2006:11-37.

10. World Health Organization: Resolution WHA41.19 Traditional medicine and medicinal plants. Geneva: Forty-First World Health Assembly; 1988.

11. World Health Organization: Resolution WHA56.31 Traditional medicine Geneva: Fifty-sixth World Health Assembly; 2003.

12. World Health Organization: Resolution WHA62.13 Traditional medicine. Geneva: Sixty-Second World Health Assembly; 2009.

13. Geissler PW, Nokes K, Prince RJ, Odhiambo RC, Aagaard-Hansen J, Ouma JH: Children and medicines: self-treatment of common illnesses among Luo schoolchildren in western Kenya. Soc Sci Med 2000, 50:1771-1783.

14. World Health Organization: Promoting the Role of Traditional Medicine in health systems: A Strategy for the African Region. Harare, Zimbabwe: WHO Regional Office for Africa; 2001. Document Reference AFR/RC50/9 and Resolution AFR/RC50/R3)

15. Tabuti JRS, Kukunda CB, Waako PJ: Medicinal plants used by traditional medicine practitioners in the treatment of tuberculosis and related ailments in Uganda. J Ethnopharmacol 2010, 127:130-136.

16. Lamorde M, Tabuti JRS, Obua C, Kukunda CB, Lanyero H, Byakika-Kibwika P, Bbosa GS, Lubega A, Ogwal-Okeng J, Ryan M, et al: Medicinal plants used by traditional medicine practitioners for the treatment of HIV/AIDS and related ailments in Uganda. J Ethnopharmacol 2010, 130(1):43-53. 
17. Gradé J, Weladji R, Tabuti J, Van Damme P: Healer-driven ethnoveterinary knowledge diffusion among semi-nomadic pastoralists in Karamoja, Uganda. Afrika Focus 2009, 22(1):57-75.

18. Almeida CFCBR, de Amorim EL C, Paulino De A, Maia MBS: Medicinal plants popularly used in the Xingó region - a semi-arid location in Northeastern Brazil. J Ethnobiol Ethnomed 2006, 15:7. doi:(Electronic article) 2:15 doi:10.1186/1746-4269-2-

19. Cunningham AB: Applied ethnobotany: people, wild plant use \& conservation. London: Earthscan Publications Ltd.; 2001.

20. Heinrich M, Ankli A, Frei B, Weimann C, Sticher O: Medicinal plants in Mexico: Healers' consensus and cultural importance. Soc Sci Med 1998 47(11):1859-1871.

21. Sofowora A: Medicinal plants and traditional medicine in Africa. Ibadan, Nigeria: Spectrum Books Limited; 1993.

22. van Wyk B-E, Wink M: Medicinal plants of the world: an illustrated scientific guide to important medicinal plants and their uses. Portland, Oregon, USA: Timber press; 2004

23. Orwa JA: Herbal Medicine in Kenya: evidence of safety and efficacy. East Afr Med J 2002, 79(7):341-342

24. Nuwaha F: People's perception of malaria in Mbarara, Uganda. Trop Med Int Health 2002, 7(5):462-470.

25. Shankar P, Partha P, Shenoy N: Self-medication and non-doctor prescription practices in Pokhara valley, Western Nepal: a questionnairebased study. BMC Fam Pract 2002, 3:17. http://www.biomedcentral.com/ $1471-2296 / 3 / 17$

26. Tabuti JRS: Herbal medicines used in the treatment of malaria in Budiope county, Uganda. J Ethnopharmacol 2008, 116(1):33-42.

27. Stangeland T, Alele PE, Katuura E, Lye KA: Plants used to treat malaria in Nyakayojo sub-county, western Uganda. J Ethnopharmacol 2011, 137:154-166.

28. Tona L, Cimanga RK, Mesia K, Musuamba CT, De Bruyne T, Apers S, Hernans $\mathrm{N}$, Van Miert S, Pieters L, Totté J, et al: In vitro antiplasmodial activity of extracts and fractions from seven medicinal plants used in the Democratic Republic of Congo. J Ethnopharmacol 2004, 93:27-32.

29. Nguta JM, Mbaria JM, Gakuya DW, Gathumbi PK, Kiama SG: Antimalarial herbal remedies of Msambweni, Kenya. J Ethnopharmacol 2010, 128:424-432.

30. Soh PN, Benoit-Vical F: Are West African plants a source of future antimalarial drugs? J Ethnopharmacol 2007, 114:130-140

doi:10.1186/1746-4269-8-35

Cite this article as: Tabuti et al:: Herbal medicine use in the districts of Nakapiripirit, Pallisa, Kanungu, and Mukono in Uganda. Journal of Ethnobiology and Ethnomedicine 2012 8:35.

\section{Submit your next manuscript to BioMed Central and take full advantage of:}

- Convenient online submission

- Thorough peer review

- No space constraints or color figure charges

- Immediate publication on acceptance

- Inclusion in PubMed, CAS, Scopus and Google Scholar

- Research which is freely available for redistribution 